\title{
Le Corbusier's Longest Journey
}

Russell Walden

If we were to ask any intelligent group of architects in the late twentieth century: 'Who combined the imaginative aspects of Rabelais, Palladio, Cervantes, Poussin, Rousseau, Viollet-le-Duc, Baudelaire, Choisy, Nietzsche, Provençal and Picasso?' the only reasonable reply would inevitably be 'Le Corbusier'.1 For us today, who are celebrating the 100th anniversary of Le Corbusier, the embarrassing feature of his work and legacy is its immense scope, the vast potential ramifications and repercussions of what Le Corbusier did or was groping towards doing. Formed as much by his milieu and unyielding will as by his idiosyncratic ways, Le Corbusier occupies a strategic position in the history of modern architecture. Indeed, the intricacies of the subject cannot be discussed comprehensively without him. He was the moral and spiritual leader of the modern movement. He exerted the most powerful form-giving influence on the architecture of the Twentieth Century. During his lifetime he was the doyen, idealistic conscience and chief propagandist for modern architecture. He inspired the deepest feelings and exercised a magnetic and barely rational hold over his followers throughout the world. He left behind him more than seventy buildings, two of which - the pilgrimage Chapel at Ronchamp (1950-55), and the Dominican Monastery of La Tourette at Eveux, near Lyon (1952-60) - can be considered timeless masterpieces.2 Besides his heroic architectural struggle - and his utopian nightmares in urbanism, Le Corbusier left some 300 paintings, and wrote thirty-eight books which were translated into a dozen languages. $3 \mathrm{He}$ also did countless articles and public lectures; as well as contributing to many exhibitions with wooden sculpture, lithographs, tubular furniture, tapestry and enamel designs. Indeed, as a propagandist, we have to go all the way back to Ancient Egypt, to Imhotep, to find an equal.

But Le Corbusier was also a very peculiar person. Ferociously egocentric and difficult to work with, he possessed tremendous vitality, high artistic perception, the deepest feelings, a sense of drama, a love of nature, and throughout his life remained an outsider to Parisian society. 4 But in the age of the herd-instinct, our fascination with him tends to increase. He was an incorrigible fighter, and a truly uncompromising figure of intense artistic integrity. We need to remember we are dealing with a combative, truculent and committed individual in whom the temperature of feeling is very high. As a designer he practised architecture and
Russell Walden graduated from the University of Auckland with a Masters of Architecture and received his Doctorate from Birmingham University. His thesis research on Le Corbusier led to his being appointed the editor of $a$ collection of essays on that architect entitled The Open Hand (MIT Press, 1977). Walden is currently employed as a Reader in the History of Architecture, Victoria University of Wellington. He has also written many articles on Le Corbusier and New Zealand Architecture and a number of monographs in the last subject area. His latest book Voices of Silence on John Scott's Fortuna Chapel, Wellington, was published in 1981 (Victoria University Press).

1. Le Corbusier always maintained that he was a self-educated person, see Le Corbusier Talks with Students, New York, 1961, p. 77.

2. For books about the Chapel of Ronchamp, see Russell Walden, Bon Anniversaire Le Corbusier 1887-1987, The loy of Ronchamp, Auckland, 1987.

3. For a complete list of Le Corbusier's books, reprints and translations, see Jacques Guiton, The Ideas of Le Corbusier, New 
York, 1981, pp. 119-122; see also Jean Petit, Le Corbusier lui-méme, Geneva: Rousseau, 1970; pp. 258-268.

4. For the difficulties of working in Le Corbusier's office at 35 Rue de Sevres, Paris, see the biography of Xenakis, pp. 34144; and Judi Loach, 'Studio as Laboratory', The Architectural Review, Volume CLXXI, No. 1079, January 1987, pp. 73-77.

5. Interview with Jean-Serge Torres, at Agence d'Urbanisme de Dunkerque, France, November 1972.

6. See Charles Jencks, Le Corbusier, The Tragic View of Architecture, London, 1972.

7. For the scandal and court case which surrounds the history of the Villa Schwob, see Maurice Favre, 'Le Corbusier in an Unpublished Dossier and a Little-Known Novel', in The Open Hand, Essays on Le Corbusier, pp. 96-113.

8. Joyce Lowman, 'Corb as a structural Rationalist, The Architectural Review, London, 1976, pp. 229-232; and Brian Brace Taylor, Le Corbusier at Pessac, Harvard University, Cambridge, Mass., in collalboration with the Fondation Le Corbusier, Paris, 1972.

9. Le Corbusier, The Radiant City, London, 1967, p. 12. preached urbanism, and was totally ignored by the French Planning profession. 5 Le Corbusier was not content to change the aesthetic direction of architecture twice within his own lifetime; 6 he aspired to be a prophet, and even to the destiny of a saint. What then was his character?

Charles Edouard Jeanneret-Gris achieved fame over night at the age of 30 with his Villa Schwob (1916-17) in La Chaux-de-Fonds. It was the first flat-roofed concrete house of the Twentieth Century for the elite of the Chaux-clockmakers. The quality of the Schwob living room has a convincing plastic unity, achieved through concrete and classicism. From being a nobody, he became one of the most talked about architects in Switzerland. But there was 'la worm in the fruit of fame'. When it was revealed late in the contract that this villa was going to cost one and a quarter million more Swiss francs (at 1970 rates) than the client expected, a whispering campaign began against him. 7 He was removed from the job, and sued by the client. The building was never quite finished as designed. His agony was acute, his personality vulnerable, and soon his character came under scrutiny, when the whole affair went to court. It took him years before he could bare to think about this painful episode. It caused him acute professional embarrassment. He wanted both to become, and to be seen to be, a different person.

With the help of Max du Bois, a Swiss engineer, Jeanneret (as he was known then) fled to Paris in January 1917. Here he eventually found a left bank garret in Rue Jacob. Du Bois also came to the rescue by finding Jeanneret a job as an architectconsultant to S.A.B.A. (Société d'Applications du Béton Arme). In this capacity he built a water tower, designed an abattoir and worker housing, and made an ill-fated attempt to run a brick factory at Alfortville. By the end of the war he was dealing in war surplus supplies. ${ }^{8}$ So in this bewildering great-war euphoria, he exchanged the regulated atmosphere of La Chaux-de-Fonds, for the manifold stimuli of a great intellectual centre.

In Paris - the symbol and synthesis of classical genius, the city of many cultural, political, and economic faces provided the essential atmosphere - the difficulties were fierce and unrelenting. But the battle of Paris was worth experiencing for it aroused mixed feelings in Jeanneret. On the one hand, living in the Latin Quarter provided the intellectual intensity he needed and provided a base from which he could broadcast his ideas using the nearby publishing houses. On the other hand, the urban phenomenon of Paris stimulated Jeanneret into a permanent love-hate relationship which he described in terms of 'a dream that I never again left'. 9 Although he loved the vibrance of the Latin Quarter in all its variety and artistic uniqueness, more and more, from the early twenties onward, the general obsolescence and multiple failings of the city as an urban unit became a constant affront to his ideas of what a great city could and should be. 
So right from the beginning of Le Corbusier's L'Esprit Nouveau years, and particularly through Vers une architecture (1923), L'Art decoratif d'aujourd'hui (1925), La Peinture moderne (1925), and Urbanisme (1925), we find him insisting that the four fields of architecture, design, painting and town-planning depend upon the product of the individual creative intelligence. Under the tutelage of Amédée Ozenfant (1836-1966), Le Corbusier had come to understand the eternal values and ideal principles found in modern tradition. 10 According to this classical horizon, architectural value could only be measured against absolute timeless standards (Fig. 3). So we have to take his idealism seriously if we are going to understand him. But to build, Le Corbusier had to fuse his idealism with political and technical realities. Herein lies the dark shadow of professional life. However, before dealing with this, it is important to stress his idealistic formation, because this is what makes Le Corbusier so peculiarly distinctive. It is his very idealism which drives him to face the large issues of contemporary life. The city, therefore, comes critically first in his thinking. Nowhere is Le Corbusier's Achilles heel more painfully exposed than when he sought to redevelop the centres of Paris and Moscow. Le Corbusier wanted to reorder these cities with a ruthlessness that would have shocked Baron Haussmann and Marshal Stalin. On the basis of a geometrical system he developed his notorious vision of high density towers, motorways and underpasses so familiar to us in the western world. But for all this visionary idealism Le Corbusier never really appreciated the effect of excesses in transportation and centralisation on people. His model was central Paris, and he took its historic right bank, and autocratically applied his heavenly vision to the Marais quarter, that area of Paris jealously watched over by the City of Paris preservationists. Between 1922 and 1946 he put forward five separate schemes for Paris, and each time he abundantly demonstrated his political naivety. 11 Now Le Corbusier always considered that he observed people's needs and thought he had the answer to solve the problem of urban decay and ugliness, but it is now quite clear, his designer's autocracy obscured any real understanding of other people. Le Corbusier conceived his plans messianically then wondered why he 'got kicked in the arse for his pains'.12 Ultimately, these rejections created a deep pathological bitterness within him. 13 This is surely a significant reason why he later rejected much of his machine-age posturing. But before this would become visible through the Mediterranean condition of his mature work, Le Corbusier pushed his idealism for the high density city to a new level in La Ville Radieuse.14 Here he begins to move away from centralised power, towards a more human city of sunshine, space and greenery. Thus, Le Corbusier moved one more step closer towards the great metropolis as the ideal form of human habitation.

By the beginning of the thirties Le Corbusier began to have doubts about large cities, and we find him reducing his 1920 s yardsticks to about a million people. 15 Such a redefinition implied a major redistribution of the population, which in turn led towards the linear industrial city. Developed between 1942 and 1962, Le
10. The Ozenfant/ Jeanneret partnership produced two books: Apres le cubisme, Paris, 1918; and La peinture moderne, Paris, 1928; two purist art exhibitions at the Galerie Thomas: Dec 1918-Jan 1917, at the Galerie Druet: 22 Jan-Feb 1921; and 28 issues of L'Esprit Nouveau, from October 1920 to January 1925 , with only four breaks in sequence.

11. See Russell Walden, 'Le Corbusier', in Contemporary Architects, (ed) Muriel Emmanuel, Macmillan Press Ltd, London and New York, 1980, pp. 460-461, and 1987 edition, Chicago and London, pp. 521-523.

12. Le Corbusier, My Work, London, 1960, p. 147.

13. Philip Johnson, Progressive Architecture, October 1965, p. 237.

14. Le Corbusier, La Ville Radieuse, Boulogue-SurSeine, 1935.

15. Anthony Sutcliffe, 'A Vision of Utopia: Optimistic Foundations of Le Corbusier's Doctrine d'Urbanisme' in The Open Hand, op. cit., pp. 220-221. 
16. Le Corbusier, La Ville Radieuse.

17. Frederick Starr, 'Le Corbusier and the USSR: New Documentation', Oppositions, The MIT Press, Winter 23, 1981, pp. 122-136.
Corbusier defined this model of urban form as a continuous belt of parallel roads and railways with housing etc. along its length. This was his most compelling contribution to urbanism. But as a means of social regeneration, the Parisian planners remained unmoved by Le Corbusier's environmental determinism.

Turning now to Le Corbusier's political dilemma, his idealistic engagement had all the waywardness of a proverbial magpie. In the twenties, he seemed the living embodiment of the conservative technocrat in wing-collar, dark suit, pipe and bowler. Here we see the posturing of a young professional trying to place his genius before banks, international corporations, and the decision makers. In his L'Esprit Nouveau pavilion, he put his plans for an ideal city for three million before Parisians. The rejection was almost instantaneous, but perhaps the bitterness was not as deep as his competition rejection for the Geneva League of Nations. These failures turned his attention eastwards. So by 1928 we find Le Corbusier making overtures to the Soviet Union, donned no less with cloth cap and rough woolly overcoat. Disillusioned by capitalism, his fascination with the radical Soviet avantgarde finds him expressing great enthusiasm, for a Communist country with a five year plan. In view of the west's broken economy, Le Corbusier made three journey to Moscow beginning in October 1928.16 Here he succeeded in realising a Centrosoyus trade union headquarters - his largest office building completed before 1945. Now, Le Corbusier was seen as Moscow's torch bearer for the 'big' idea. While never a Communist party member and not even a Marxist in any rigorous sense of the term, Le Corbusier embarked on the Centrosoyus building with a fervour that rivalled that of its sponsors. 17 Clearly, Le Corbusier had absorbed the heady utopianism of the First Five Year Plan. But all this euphoria turned rather sour, when the Soviets refused to use air-conditioning. On top of these Centrosoyus squabbles followed another painful rejection of his 1931 Palace of the Soviets competition entry. This coup-de-grace effectively ended his flirtation with the Soviet Union. Returning to Paris he became a tireless spokesman for indigenous French socialism, which called for the trade unions to take over the means of production. Now Le Corbusier's conversion to syndicalism was no doubt comforting to those who wished to identify modern architecture with leftish politics; nonetheless, it still fails to define the real Le Corbusier. His activist period of the thirties was also characterised by his growing fascination with authoritarian, quasi-fascist groups at the fringes of French political life. After the fall of France, in the long hot summer of June 1940, this fascination with a Nietzschean will to power became commitment. He announced his allegiance to the reactionary right-wing regime of Marshal Pétain, and sought to join the government himself. Now Le Corbusier spent eighteen fruitless months at Vichy, hoping to become the great dictator of French architecture. Most certainly, this waywardness, was not his finest hour.

As a politician, Le Corbusier's engagement had all the shortcomings we associate 
with the intellectual in politics. During his political wilderness, Le Corbusier was certainly opportunist, sometimes utopian, and usually spiteful and unco-operative. Robert Fishman in The Open Hand certainly put his finger on Le Corbusier's pulse when he wrote:

'Le Corbusier was as sensitive to his prerogatives as he was insensitive to the rights of others. Indeed, for a life long proponent of organisation, Le Corbusier was singularly incapable of working within one.'

'Yet, if his activism had its miseries, it also had its quixotic grandeur. Even at Vichy Le Corbusier never lost his dedication to his own complex vision of a harmonious future.'18 For him, politics existed only to provide authority for the great works of reconstruction. Now towards the end of his first visit to Chandigarh in 1951, he was moved to record the main members of the architect team, during which he drew himself as a raven. So the analogy of political magpie comes close to the master's perception of himself.

From his political waywardness, I want to turn to his technical dilemma. Here we have another vulnerability. For most of his life Le Corbusier spent his mornings painting, so he cannot really complain if the world has 'seen him as an "art" architect and largely ignored his attitude to construction and building technology'.19 The truth of the matter is that he had little technical background.20 Nor was he a builder, but he did have technical ideas.21 Moreover, he desperately wanted to personify the ideal of l'homme engagé, the intellectual who was also a man of action. Ironically while Le Corbusier wrote manifestoes to the machine, his purist villas had frequent problems with leaking and condensation, while his artificial lighting systems were clearly inadequate, with frequent break-downs in the heating systems. His idealist approach can be indicted for substituting a symbolic machine aesthetic for technologically viable buildings. Now while Le Corbusier made a lot of noise about 'the house is a machine for living in' - machine a habiter he called it the truth of the matter is that Le Corbusier's concern with purist morality never carried him behind the walls of his buildings to consider the plumbing. As Brian Brace Taylor put it - 'The general mystification surrounding Le Corbusier and his Oeuvre arises from the following paradox: a prolific writer, experienced lecturer, and irrepressible strategist, he extolled the virtues of efficiency and rationality in planning, while continuing to practise his profession as a designer in the idiosyncratic ways of a traditional craftsman'.22 But idealistic architecture was clearly a state of mind for Le Corbusier. As he saw it, architecture was an art, a phenomenon also of the emotions, lying outside questions of construction and pragmaticism. For him, it was never enough to provide just a technical solution to an architectural problem. For, 'Architecture is the masterly, correct and magnificent play of masses brought together in light'.23 From this lyrical definition, we can sense that Le Corbusier's approach to design was essentially intellectual, and
18. Robert Fishmann, 'Le Corbusier's Plans and Politics, 1928-1942', in The Open Hand, op. cit., p. 246.

19. John Winter, 'Le Corbusier's Technological Dilemma', in The Open Hand, op. cit., p. 323.

20. Russell Walden, 'Le Corbusier' in Contemporary Architects.

21. Interview with André Wogenscky, 24 Rue Nungesser-et-Coli, Paris, 20 November, 1975.

22. Brian Brace Taylor, Technology, Society and Social Control in Le Corbusier's Cite de Refuge, Paris, 1933', in LC 1905-1933, Oppositions, 1979: No. 15/16, p. 183; and La Cite de Refuge di Le Corbusier, 1929/31, Officina Edizioni, Roma, 1979.

23. Le Corbusier, Vers une architecture, Paris, 1923, English trans. Towards a New Architecture, 1952 edition, p. 31 . 
24. Ibid, p. 140.

25. Alan Colquohoun, "The Significance of Le Corbusier', in The Le Corbusier Archive, Vol. I, p. xoxv.

26. Le Corbusier Sketchbooks, Volume 2, 1950-1954, Thames and Hudson, London, and Fondation Le Corbusier, Paris. Notes by Francoise de Franclieu, D14 Sketchbook, February 1950, p. 7.

27. Jerzy Soltan, 'Working with Le Corbusier', in The Le Corbusier Archive, Volume XVII, pp. ix-xxiv.

28. See Stanislaus von Moos, Le Corbusier, Elements of a Synthesis, MIT Press, Cambridge, Massachusetts, 1979, p. 92 . See also footnote 76, Chapter 3. spontaneously subjective. He was also fond of ambiguity, hence his work has many layers within it. His architectural currency dealt with forms in light - emotional relationships, and the promenade architecturale. As he saw it, the 'business of Architecture is to establish emotional relationships by means of raw materials'.24 But the mysterious quality of his work, stems from the fact that he always attempted to reconcile the conflicting tendencies between spiritual ideals and material realities.

As Alan Colquhoun put it: 'If this idea of the fusion of art and technology was at the basis of modern movement theory, in the case of Le Corbusier it was combined with a concept of architecture derived from an older tradition - that of classicism. According to this view, architectural value could only be measured against an absolute and timeless standard'.25 Hence his life-long poetic struggle 'to re-establish a state of harmony between man and his surroundings, a harmony disrupted in his eyes by machine civilisation'.26

Jerzy Soltan has written about the pains of Le Corbusier's creation.27 But it is surely one thing to assert that art transcends reality, and another to actually fuse the classical values of an older tradition within the technological demands of an industrial culture. Yet it was just such an idealism that drove the classical wing of the modern movement. Be this as it is, the act of building was surely a painful dethronement for Le Corbusier.

Up until 1940, his collaborator cousin Pierre Jeanneret attended to the technical side of the practice. For he had a surer grip upon the technical realities of professional life. But clearly, Le Corbusier could not ignore the technical problems associated with the large building commissions of the late twenties and thirties. Indeed for Le Corbusier these difficulties were a considerable burden. Whether his office was building for 20 below in a Russian winter, or 20 above in a Parisian summer, Le Corbusier ran into a barrage of technical difficulties. Somehow these unaccommodating difficulties were sorted out. The Centrosoyus acquired its double skin of glass, the Cite de Refuge, and the Swiss Pavilion their brise-soleil. But it did not arrive until after World War 2. Nor did it arrive without struggle and embarrassment. Le Corbusier never capitulated. Like an incorrigible Don Quixote he continued to test his lance, by pushing himself hard. His struggle to build in machine-age materials was certainly made more acute by the steel and glass success of Pierre Chareau. Chareau's mastery of invention and precision, produced the poetry of the Maison de Verre. This isolated building was certainly the first machine-age shock by an artist-architect. Le Corbusier was never slow to spot a winner. He became Chareau's secret disciple. 28 A man of his time, Chareau admitted no compromise. His example and influence was as clear as in the glass-brick facade of Corbusier's Rue Nungesser-et-Coli apartment block. On top of this steel and glass clad building, came the mature penthouse commands that changed the condition of Le Corbusier's architecture. Within a few years he achieved the 
transition from the hard edged architecture of the classical villas, to rustic buildings with thick walls in chunky concrete. Thus, in Le Corbusier's long struggle to find himself, he took a different stance from the position he adopted in Vers une architecture. The driving spirit behind the ruggedness of his invention, derived from his penthouse study - a true plastic sanctuary of silence - 'a secret laboratory - was a generator of forms'.29 In silence, above the Rue Nungesser-et-Coli, his plastic metamorphosis took place. In this monastic atmosphere, the final definition of Le Corbusier's idealistic and tragic persona was born.

To this haven of monastic silence, a very bruised Le Corbusier returned in July 1942, following his attempted rapprochement at Vichy. Here in Paris Le Corbusier found his roof garden overgrown with weeds and decay everywhere. Even the metal frames of his apartment's pan de verre were all jammed up with rust and deterioration. Such a scene perfectly matched his disenchantment with authoritarian regimes such as Vichy. Nursing a wounded consciousness, Le Corbusier renounced the pre-war enthusiasms of European fascism. The terror of war, the occupation and its lack of food totally overwhelmed him.30 The post-war scene was just as threatening - the devastation and terrifying uncertainties, the war dead, the missing persons, the gutted cities, the broken bridges, the widely publicised war-crimes, the horror of Belsen, Auschwitz and Buchenwald. 31 Le Corbusier felt revulsion at the horrors of totalitarianism. The evil of Hitler's war, which pushed humanity way beyond the horizon, did not escape him. This deep psychological trauma, leads directly to a consideration of Le Corbusier's development as an artist.

As an artist-architect, Le Corbusier was deeply receptive to the lessons of nature and history. Throughout his long career, he maintained the French artist's habit of the sketchbook. Through the visual diary, he fixed in his memory the spontaneous record of significant visual experiences - silhouettes, interactions between horizon and sky. In this way he recorded the heroic and humble events of life. People in public and in private are revealed in fleeting impressions - the gift of a quiet eye. Le Corbusier's notebooks, more than seventy in all, provide the private and poetic response of his inner and longest journey. 32

Now, Le Corbusier understood the notion of the artist as genius, seer and visionary prophet. He placed stress on the spontaneous expression of emotion. This side of his psyche was clearly dominated by feeling - by Romanticism. But the high Romantic in Le Corbusier was countered by another facet of his personality - that side of him which drove towards a preference for harmony. This more classical aspect of his personality explains his preoccupation with images of the ideal, and eternal principles. 33 These two sides of his personality - Romantic and Classical, spiritual and material, Dionysian and Apollonian reflect the polarities of his vision, and his pursuit of ambiguity. As Paul Turner put it: 'This multiplicity is not simply
29. Le Corbusier Sketchbooks, Vol. 3, 1950-1954, Thames and Hudson, London, Fondation Le Corbusier, Paris. See D16

Sketchbook, January 1950, p. 11.

30. For Le Corbusier's reaction to the horror of concentration camps: Le Corbusier Sketchbooks, Vol. 3, 1954-1957, see L46 Sketchbook, January 1957, ref. 835, p. 68.

31. For images of horror from Buchenwald: ibid, p. 68. For further reactions to world crises, see Sketchbook 3, Nov-Dec 1955 , specifically Sketchbook J38, ref. 410, $\therefore$... Civilization is a terrible drama. What distinguishes its great moments from its dissolution and failures is the courage to accept risks, and the power to overcome its disorders (through) serenity of heart'. See also Richard Cobb, French and Germans, Germans and French, University Press of New England, Hannover and London, 1983; and David PryceJones, Paris in the Third Reich. A History of the German Occupation, 1940-1944, London, 1981.

32. Le Corbusier Sketchbooks: Vol. 1, 1914-1948; Vol. 2, 1950-1954; Vol. 3, 19541957; Vol. 4, 1957-1964; represent 70 notebooks where Le Corbusier recorded the spontaneous thoughts of his career as an architect. They provide positive evidence of Le Corbusier's poetic creative life of inner struggle. Currently the only remaining sketches to be published are the early carnets, dating from 1911 to 1914 . These represent the earl iest years in $\mathrm{La}$ Chaux-de-Fonds. See Le Corbusier, Voyage to the 
Orient, New York: Rizzoli, 6 Volume boxed set, 1988.

33. Russell Walden, 'Le Corbusier's Ronchamp', NZIA Journal, 1, 1977, pp. 26-43.

34. Paul Turner, 'Romanticism, Rationalism, and the Domino System', in The Open Hand, op. cit., p. 15.

35. William J R Curtis, Le Corbusier Ideas and Forms, Rizzoli, New York, 1978, p. 8.

36. See Le Corbusier Peintre, Basele, 1971, p. 5 . Also Sketchbook 4, p. 60. Ref. 506, 'Painting is a terrible battle, intense, pitiless, without witness: $a$ dual between the artist and himself. The battle is internal, ... unknown to the outside. If the artist tells about it then he is a traitor to himself'.

37. See Lynn Hanney, Naked at the Feast, The biography of Josephine. Baker, Robson Books, London, 1981, 'Le Corbusier enjoyed his liberties when travelling. Women generated an intense excitment in him, which he considered moral by its very force'. p. 157.

38. Reyner Banham, 'La Maison des hommes and La Misere des villes: Le Corbusier and the Architecture of Mass Housing', in The Le Corbusier Archive, Vol. XXI, 1983, pp. IXXVIII.

39. Nikolaus Pevsner, 'The AntiPioneers', in The Architects' Journal, London, 1 February 1967, pp. 279-280.

40. See Jones $C$, Wainwright $G$, Yarnold E, The Study of Spirituality, SPCK, London, 1986, p. 535. in the observers' eyes but is inherent in the work itself and, more than that, in its underlying theoretical foundation'.34 This very dualism accounts for the collaged expression of line against curve, plane against volume, symmetry against asymmetry, form against grid, and the sensual against the abstract. As a form-maker, Le Corbusier was 'the supreme dialectician'. 35 So Le Corbusier was a man of both intellect and spontaneous emotion. As he admitted in 1948: 'I believe that if one gives any importance to my achievement as an architect, the true reasons for it may be found in this hidden labour [as a painter]. 36 Clearly painting provided the spiritual energy for all his plasticity.

Settling in Paris, the cultural eye of Europe, Le Corbusier began by giving his stilllifes of the early twenties a classical restraint which appeared to match the new morality of mechanisation. By 1928, women and the human condition had replaced purism. In December 1930 he married Yvonne Gallis, who patiently helped him towards a Mediterranean metamorphosis in the light of Provence - that part of France that had liberated Cezanne. By the mid-thirties this liberated condition could be seen in his paintings. The Dionysian side of his psyche leaped energetically forwards. His paintings from there on glory in curvaceous forms, which leave no doubt about the influence of women in his life.37 In his post-war architecture women and children were certainly glorified on the promenade deck of his Marseilles Unité, with its kindergarten and paddling pool on the roof-terrace, a creche and extensive built-in furniture within the apartment block. Further, the curvaceousness of women in general has surely influenced the gargantuan earthmother, strong-leg forms of the piloti. We sense here the uncensored form-maker in heroic pursuit of the Fourierist temple to the family. Reyner Banham must surely be near the mark, when he suggested that the Marseilles Unité is 'one of the ancient monuments of modern Europe'.38 Certainly the primitive perception of this building was the imagery which seduced generations of architects to the Mediterranean. Architects as a group never flock easily; but all this shock of the primitive appeared just at the point in the post-war scene when heroes were out of favour in Europe. At this psychological moment, when the human cry was not even unambiguously human any more, Le Corbusier struck with all the compulsive thunder of a rank outsider. He revolted against authority, against the psychological disruption of evil; he revolted against bureaucracy, against the flood of laws, regulations and encroachments against the individual. At this very moment in modern architecture, we come face to face with the modern master for the first time, and we experience the shock of the old in the new. From then on, it was possible to review his secret metamorphosis which included objects of poetic reaction, the human modular, and the nude. This mature work was certainly not understood, and some academics like Nikolaus Pevsner were openly dismayed. 39

At this point the meaning of Le Corbusier's Longest Journey begins to unfold. His longest journey is, of course, his journey inwards. 40 From that time on Le Corbusier 
embraced humanity with a born-again vengeance. Significantly his post-war buildings became instant tourist attractions. They all glory in a plastic monumentality in harmony with nature. In a series of compelling gestures after 1945, Le Corbusier began to turn the modern movement on its head. Gone were the thin walls and sweet-pea colours; gone were the purist hymns to machine morality. We need to remember artists of real talent can never be understood as predictable creatures. Not surprisingly out of the ruins of the thirties and forties, Le Corbusier turned and faced post-war sterility head-on.

Of his mature work the building which most demonstrates Le Corbusier's plastic development is his pilgrimage chapel of Ronchamp. This is his most enigmatic building. He referred to it as the 'pearl of my career'.41

In this commission he unashamedly and passionately responded to nature and her inherent rhythms. When he stood on the high point of Bourlemont in 1950 and savoured the atmosphere and visual vibrations of the surrounding Vosges landscape for the first time, he became deeply committed to designing this chapel of pilgrimage. He was never given a theological programme - 'it was agreeable for once, to become absorbed in a disinterested problem without any real practical programme'.42

Le Corbusier acquainted himself with the limitations of the existing chapel whose war-damages state suggested that it be dismantled. There was the usual hue and cry, since this chapel had been in use since the twenties, but the War Damages Commission could provide a subsidy towards a new chapel. Le Corbusier was determined not to disappoint them. He appreciated the fact that this site had a long historical lineage that went back before Christ, when a pagan temple was first raised for sun worship. So to build on this ancient site was a high challenge.

Undaunted as ever by the fact that the site had no real access road from the village, he would have to build in concrete; stones from the ruin would do for fill, but certainly not for load bearing. Le Corbusier spent time getting to know the ground and the horizons in great detail. His creativity always compressed many levels of consciousness. The fluidity and intensity of his first charcoal drawing suggests that the birth of Ronchamp was a mystical moment of illumination, preceded by a period during which the architect lost himself in the contours of the four horizons. As an act of creation, it could be likened to the intense concentration and outpouring of the pilgrim traveller in search of a union between the Absolute and the Real. These two experiences tend to become obscured through the architect's creativity, but in the mystic's 'attempt to philosophise on his experience he is bound to separate them. Over and over again the mystics and their critics acknowledge, explicitly and implicitly, the necessity of this discrimination for human thought'.43 As a designer, the collaged collision between his idealism and the practical realities is the dualistic
41. Le Corbusier quoted in France Dimanche, No 356, 21 June 1953, p. 15.

42. Le Corbusier, Oeuvre complete 1946-1952, p. 76.

43. Evelyn Underhill, Mysticism, London, 1942 edition, p. 108. 
44. See Russell Walden, 'Le Corbusier, Ideals and Realities'.

45. Le Corbusier, The Chapel at Ronchamp, London, 1957, p. 89.

46. René Bolle-Reddat, Our Lady of the Height, Ronchamp, Munich and Zurich, 1965, p. 6. tension ever present in all his thought and work.44

Of the four horizons surrounding the Ronchamp promontory the most dramatic view is towards the south sky where it meets the terrain of the Vosges. Beyond this horizon is Switzerland - Le Corbusier's homeland. From the same direction also comes the full power of the sun; and to all these stimuli Le Corbusier was most sensitive. He responded first to the south horizon with an in-swinging wall. As a solar receiver it was bent back before nature, the sun and the Vosges horizon. The east wall followed logically within the discipline of the pilgrims' anti-clockwise route. Next came the counter curves of the outdoor sanctuary and esplanade which took the form of a crescent before the outdoor altar. In this way the pilgrims were gathered together in nature, before the outdoor altar table. To complete the plan, all that remained was for Le Corbusier to close up the remaining north and west sides with straight lines.

As an act of creation, this charcoal drawing represents the mystical evocation of the four horizons of Ronchamp. Le Corbusier made no secret of the importance of these, openly admitting, 'It is they which unlocked, architecturally, the echo, the visual echo in the realm of shape'.45 In this matter Le Corbusier revealed himself abundantly as a nature mystic.

When visitors try to fathom the poetry of the walls of Ronchamp, they usually have some difficulty locating those areas of the horizons which spoke to Le Corbusier. To find the essential landscape profiles which triggered Le Corbusier's poetic responses, time has to be spent in patient discovery. In this comprehension it helps to see the walls and crab-shell roof as 'receptacles best suited to light and to music; concave mirrors, panoramic screens, loudspeakers shaped like shells, radar instruments which are both receivers and diffusers'. 46

Although the birth of the plan form took Le Corbusier not more than a dozen strokes of charcoal, we must remember that a lifetime's preparation had enabled the artist to imaginatively capture the four horizons of Ronchamp within the discipline of the pilgrims' route, as they meet on the climb and as they encircle the hill of Bourlemont.

For a consideration of the building volumes, the first clues are to be found in his sketchbook 'E 18'. In these sketches we find the first three-dimensional elaboration of the concept. From this series of drawings it is clear that the Chapel of Ronchamp was not going to be like anything previously built. Its shell roof, dominating walls and hooded towers completed a composition unique in the history of religious architecture.

When talking about the birth of this project, Le Corbusier said that after finding a 
crab shell on Long Island beach in 1947, he noticed how strong it was when he put his weight on it. He kept this shell, and poetically it inspired in him the idea of the chapel roof. It was a sympathetic form for the plan he had in mind. Yet Le Corbusier did not simply place the crab shell in the architectural space, he elaborated upon it and transformed its appearance.

Almost in the same spontaneous way, Le Corbusier came up with the form of the towers that overlook and illuminate the secondary chapels. From his storehouse of memories, he took over the idea of using light wells from the Villa Adriana at Tivoli, Rome. From this conceptual collage, we see how Le Corbusier established the first ideas which were all in place by June 1950 . Staged development sketches continued, but from the beginning we need to understand how Le Corbusier's poetic response to nature affected the birth of the building.

The idea of pilgrimage, of worship before the spectacle of nature, appealed to Le Corbusier's developed notion of the spiritual. The site was on a high point above the village of Ronchamp, where the surrounding configurations of earth and sky reveal a rare richness - both basic and profound. For this reason the building is one of his most revealing commissions. Ronchamp is the meeting place of the sense world and the spiritual. In his nature mysticism he unrelentingly projected the principle of a spontaneously free creative life as the essence of reality, and gave instinctual expression to the whole of nature, that aspect of creation neglected by Christianity.

This distinctive inspiration can be explored from the other end of the project, from the point of view of furnishing and detailing. By taking the architectural promenade, starting from where the pilgrims arrive on the hill, entry is by the principal south door. This exterior door is an exclamation of colour. It is a signpost of the inner journey that had been going on within Le Corbusier's psyche, ever since he left La Chaux-de-Fonds. So while the exterior door welcomes the pilgrim, the interior panels are concerned with the Virgin: Notre-Dame-du-Haut.

Considering the eight exterior panels first, we notice that Le Corbusier uses symbols to draw attention to the nature of pilgrimage. Set within an invisible horizontal framework, this door draws attention to the longest journey of the pilgrim through the fog of life's journey; while red and blue hands either side of cogwheels signify giving and receiving within our working lives; above this is the biblical sign for the presence, a red and blue cloud. The whole scene is a multiplicity of alternating colour within a secret geometry. Here then is the welcome that greets the weary pilgrim from the four horizons. While the exterior panels suggest life's spiritual encounter, those of the interior deal with initiation and intercession through the Virgin, Notre-Dame-du-Haut. These doors are concerned with the dilemma of contemporary men and women, and they deal with spiritual regeneration: a post- 
47. Le Corbusier Sketchbook 4, March-April 1961, R 63, Ref. 690: 'These Taureaux $=$ total and intimate confusion, Corbu-Yvonne, my constant, sick, dying, dead wife $=$ the Taureaux!!'. war issue of critical concern.

When we consider the interior panels in detail, we find Le Corbusier again uses signs and symbols from nature and the world. This time the generating lines of the composition are vertically centred. At the bottom of this door Le Corbusier has used chaotic bull symbols which have feminine connotations in his mind.47 Above are the spiralling red flames of intercession to the Virgin, then the forgiving hands which lead to the gold triangle - a comment about ultimate reality. Though the pilgrim is called, the route to spirituality is long and difficult. It relates to the lonely struggle of the pilgrim for inner peace and fulfilment and the tortuous path of the longest journey is also certainly autobiographical. Le Corbusier never explained these panels, but when we understand his nature mysticism, as well as his creative struggle as an architect, they can be meaningfully interpreted. Further assistance in interpretation comes from the number of preliminary studies made for both sides of these doors. They are of fundamental importance to the project as a whole.48 Indeed, without them the building is meaningless. To discover the hidden meanings of these doors is part of the pilgrimage encounter.

Other than the principal south door, the only other element in the building to be treated in a similar manner is the white tabernacle on the main altar. This enamelled-steel tabernacle contrasts sharply with surrounding textures, particularly with the hand-thrown rendering of the east wall.

The tabernacle is a simple cubic form on three supports with a small door which encloses the eucharistic elements. This door is painted with the signs of the cosmos and the paschal lamb. On its right side Le Corbusier has images of a butterfly, two four-winged birds and a moth. The left side of the tabernacle is reserved for flowers and leaves, while the rear panel received the silhouettes of trees and mountains. A cross containing a crucifix surmounts the tabernacle, as is required by canon law. This allows the main cross to be positioned free of the main altar and beyond the vision of the celebrant, thus providing a unity in the composition of the freestanding elements. For the detailing and signs of the tabernacle, nature is the source from which Le Corbusier has drawn stimulus. This is another potent example of the expression of Le Corbusier's spirituality.

Continuing the architectural promenade, we immediately discover with the windows of the south wall that Le Corbusier has used the same iconographic language that first appears on the principal door and then the tabernacle. His deeply-splayed wall niches contain clear and coloured glass, which Le Corbusier has painted in metallic oxides. Again he has used images of birds, butterflies, flowers, leaves, the sun and moon, stars and clouds. His images sing praises to nature. At the same time there are several phrases referring to our Lady, such as 'je vous salue, marie'; 'pleine de grace'; 'bénie entre toutes les femmes'. The decision to 
give the space an ethereal quality by using this manner of lighting is a clear rejection by Le Corbusier of stained glass in contemporary architecture. Moreover, while selecting the overall intensity of light required for the interior, Le Corbusier has also placed emphasis on positions of liturgical importance. For example, his window 'etoile du matin' and its neighbour 'la mer' provide an unforgettable accent and richness to the memorial act of candle lighting.

While under the magic of the south wall which curves and splays in three dimensions, we cannot ignore the bench pews built lovingly by Le Corbusier's Breton friend, Savina. This sculptor was the only artist Le Corbusier invited to help him in his chapel. Savina's eight benches have been beautifully shaped with a strong hand sympathetic to the use of timber. These benches are placed and fixed on an upstand under the glow of the south wall. They occupy only ten percent of the nave, but Le Corbusier must have regretted having to have any at all.

Savina also hand-made the sanctuary cross and the confessionals. Le Corbusier's instructions to Savina on the quality of the woodwork were quite specific: 'I cannot admit to having doors shaped by machine'.49 Certainly the artistry of Savina's confessional doors are sensitively set within the geometry of the west wall. This wall flows rhythmically into a returning loop containing the south tower which sheds a continuous stream of light downwards on to the side altar.

The south-west tower receives almost continuous light as its cupola faces north. The other two smaller towers face east and west, and therefore receive morning and afternoon light respectively. These three towers catch the sun as it moves around the building, and in the process become dynamically alive. 'The key is light, and light illuminates shapes, and shapes have an emotional power'.50 This chapel is a synthesis of light, nature, form and the liturgy.

From observations of the interior, we can say that Le Corbusier's theological task was to give expression to the domesticity of the Mass, 51 the sacrifice of Christ and the Church, 52 and the intercessionary offering of these dimensions through the Virgin: Notre-Dame-du-Haut.53 As architect of this chapel, Le Corbusier had to provide a place for individuals to share the meal together, a place to share in the celebration and the sense of the tragedy of sacrifice, and a place to share the corporate action giving due regard to the intercessional value of private devotion to the Virgin. These were the theological criteria.

For the celebration of the most holy mysteries, Le Corbusier received liturgical guidance from Lucien Ledeur and Abbe Ferry. $54 \mathrm{He}$ began with a Burgundy stone altar. This was placed on the central axis and given the human proportions of a table. Behind and to the right, the cross of human tragedy was positioned in the floor. Above and further to the right was positioned the wall Virgin. The Virgin
48. For a full discussion of the Ronchamp doors, see Le Corbusier, Ideals and Realities', pp. 419-434.

49. Le Corbusier letter to Savina, 8 February 1955, Archives Fondation Le Corbusier, hereafter AFLC.

50. Le Corbusier, The Chapel at Ronchamp, p. 27.

51. See Charles Davis, Liturgy and Doctrine, London, 1960, p. 10. Also Fredéric Debuyst, Modern Architecture and Christian Celebration, London, 1968, pp. 9-19.

52. See Jungman, J A, The Sacrifice of the Church', The Meaning of the Mass, London, 1956, p. 1.

53. See Dom Gregory Dix, The Shape of the Liturgy, London, 1945, p. 2.

54. Abbé Ferry, letter to André Maisonnier, 15 April 1955, AFLC. 
55. Abbé Bolle-Reddat, 'Miettes' in Journal de Notre-Dame-duHaut, Ronchamp, December 1971, p. 6.

56. Ibid, p. 8.

57. Ibid, p. 16.

58. Quotation from Abbé Marcel Ferry, in Jean Petit, Le livre de Ronchamp, Paris, 1961, p. 12. dominated the composition, which was balanced by the candle holder and the asymmetrical placement of Savina's bench pews. The whole composition was a dynamic one, in which Le Corbusier communicated the characteristics of domesticity and monumentality, mystery and peace. In this way, the architect satisfied the details of Catholic liturgy, while being true to himself.

Yet, what did the users and passers-by think of this building? Abbé Bolle-Reddat, the Chaplain of Ronchamp, recorded many experiences from pilgrims and casual travellers. From a young man, Bolle-Reddat noted: 'The first time ... I was quite filled with prejudice against this modern chapel ... but I have ended up allowing myself to accept the invitation to silence, to meditation and to prayer'.55

From a woman Professor of Art History: 'I have visited so much ancient and modern architecture ... this is the most extraordinary that I have seen. I have never been affected like this before. I am an atheist, but I had to light a candle, for me that is very significant ...'.56 Clearly we cannot disguise the emotional impact on people of this cave-like grotto. Nor can we discount these dimensions of spiritual response within the religious experience.

Abbé Bolle-Reddat took this question further when he described the chapel interior under the metaphor Marie, belle comme la lune. 'Enter the sanctuary, as a visitor or as a pilgrim. Both must here seek before all else the Presence and meditation. He calls upon his spiritual sensibility. The practising Catholic will perhaps not find straight away the usual context of his prayer. But many who thought they were strangers to worship in spirit and in truth are amazed at being affected and moved ... Silence ... A great sign appeared in the sky: a woman, dressed in sunlight, a crown of stars around her head, at her feet the moon.'57

Abbé Marcel Ferry, a member of the team of clerics who looked after the chapel before the permanent Chaplain was appointed, wrote: 'The chapel complies admirably with the profound life of the liturgy. The pilgrims visit it faithfully as before. One can pray there without growing weary, for whole hours, when the tourists do not interrupt with their noise and their indiscretion. One can find there - on this point all opinions are in agreement - an authentic spiritual atmosphere, poverty, peace, joy, grandeur, the essential traits of the Gospel. The architect, in effect, has disciplined his lyricism through an unrelenting will and through an undeniable sense of the sacred'. 58

We should not leave this chapel without noting what the architect thought: 'Not for one moment have I had the idea of making an object of wonder. My preparation? A feeling for others, for the stranger, and a life which had passed in the brutalities of existence, the spitefulness, egoism, cowardice, trivialities, but also so much kindness, goodness, courage, impetus, smiling, sun, sky. And a resulting choice; 
taste, need of truth. Ronchamp? Contact with a site, siting in a scene, eloquence of the scene, word addressed to the scene. To the four horizons'.59 This passage, particularly the last phrase, is a potent reminder that Le Corbusier's spiritual communion with nature far outweighed the mystery of the Catholic Mass. The question of Le Corbusier's religious attitude has puzzled everybody, yet nobody has managed to provide a satisfactory explanation. Perhaps the nearest is that provided by Father Monier who said, 'Le Corbusier was himself, that is what is the most important'.60

To celebrate the pilgrimage Mass outdoors before nature was in great sympathy with the architect's approach to the spiritual. He was supremely receptive to the world of nature, and before nature he was himself. When we consider his solution to the outdoor Mass, the witness before the altar and before nature, we cannot deny the masterful timelessness of Le Corbusier's solution. His cycloramic backdrop makes sense in terms of the liturgy and acoustics, and at the same time the chapel has become a perfect receiver of nature. It is open to pilgrims, open to travellers, open to passers-by from the four horizons. Nature, in fact, has become the loudspeaker for Le Corbusier's architecture. From this chapel, we can sense that Le Corbusier believed in some sort of Benevolent Being and had sympathy with the idea of a simple return to the ideals of the past. Le Corbusier was concerned for a society clearly beset by deep inner poverty. He was a storm centre during his lifetime but the inner core of this man is a massive indictment of the established order. Le Corbusier, like Rousseau before him, aspired to a new order. His intentions may or may not have been revolutionary, but his remarkable imagination certainly was.

All his final work was deeply personal. It expressed a profound hope for the future, for Le Corbusier's work was passionately rooted in something real and vital in his own experience of life. At the pilgrimage Chapel of Ronchamp, Le Corbusier came as near to expressing his inner voice as he ever came to do. In this commission he successfully resolved the ideals and realities of the situation. Now, it is this singular magical moment which should move us. For Ronchamp is a timeless contemporary masterpiece. It is an architecture in deep communion with primeval and timeless instincts.

In conclusion, Le Corbusier's architecture commands our emotional and intellectual attention. His life and work provide a series of expressions of his agonising creative journey. If his architecture differs from the herd instinct, it is because he had the capacity to endure creative isolation. This irony may be complex, but the message is plain.

Although his final work was more human and personal than his purist concerns of the twenties, the difference between these two periods is one of degree, not of kind.
59. Le Corbusier quoted in Jean Petit, Le livre de Ronchamp, p. 18.

60. Abbé Bolle-Reddat in Journal de Notre-Dame-duHaut, December 1971, p. 8. 
His purist years were under a discipline of idealised object-types, while his final concerns had a more obvious and richer affinity with nature and the human condition. This is all the more apparent when we have personally experienced the psychological condition of the Mediterranean. Therefore, we have to answer ' $\mathrm{No}^{\prime}$ to the question of whether or not Le Corbusier's vision as an architect changed radically. However, it must be admitted that, until he built Ronchamp, his nature mysticism was not fully visible to the world.

Finally how good an architect was Le Corbusier? Clearly Le Corbusier was a colossus when designing for projects which required a profound degree of spirituality - such as when designing for silence and inner renewal. But as an architect-planner - when designing cities - his creative autocracy often led him towards sterility and worse. However, like most of the modern pioneers, Le Corbusier's personality mirrors all the major problems that have beset the Twentieth Century: authoritarianism, fascism, opportunism and creative autocracy. Politically, his dilemma was that he operated as a nature mystic in the age of the masses. As a god-like operator, he was doomed to suffer defeats. Le Corbusier was rejected in Moscow, Geneva, Paris, and New York. He was also rejected by Vichy. When he acted like a god, the gap between his idealism and the political realities was one that could never be closed. However, when commissions came to him where he could respond with total freedom as a nature mystic, he created architecture that was not only original within the period in which he worked, but also within his own oeuvre. Le Corbusier remained creative right to the very end.

As an artist-architect Le Corbusier could be both devastatingly brilliant, and an overwhelmingly tragic figure, depending upon the circumstances. Where the architect's mysticism was alien to the socio-political programme, there was stalemate. But where the architect's vision coincided with the requirements of the client's situation, he achieved masterpieces of imaginative force and deep inner conviction, particularly at Ronchamp and at La Tourette. Both buildings are major works of genius which profoundly express his visionary idealism, his sense of history, and above all his compelling nature mysticism. In these buildings we stand in the presence of a man with a destiny. He was master of his own fate, faithful only to himself, lonely as the sun, but one who glowed with much the same intensity. 